Door Bernadette Kester

\title{
In memoriam Bart Hageraats (1950-2014)
}

\section{Door Bernadette Kester}

Zo'n vijftien jaar was Bart de eindredacteur van het Tijdschrift Mediageschiedenis. In die periode fungeerde ik zelf als redactielid respectievelijk als voorzitter van de redactie. We hadden dan ook zeer geregeld contact. Bart vatte zijn taak niet licht op, maar wel op een luchtige manier, terwijl hij meer deed dan menig eindredacteur normaal zou doen. Behalve dat hij een zeer nauwgezette en geduldige eindredacteur was, bezocht hij alle redactievergaderingen en schreef daarvan uitgebreide notulen. Die notulen bestonden dan uit minimaal vier dichtbedrukte pagina's (voor anderhalf uur vergaderen!). Bart beschreef minutieus wat zoal ter tafel kwam en verschafte ons dan ook onmisbare documenten, te meer omdat we soms maar twee keer per jaar vergaderden. Onder andere hiermee had hij zich in de loop der jaren onvervangbaar gemaakt.

Bart nam een bijzondere plaats in binnen de redactie, niet alleen omdat hij als enige niet aan een universiteit was verbonden, maar ook qua persoonlijkheid en verschijning was hij uniek: hij was de oudste, de enige met een snor en een pijp, en qua kleding leek hij meer op een boswachter dan op een mediahistoricus. Hij was zeer belezen en erudiet. Geweldig dat hij het nog voor elkaar heeft gekregen een proefschrift af te ronden waar hij zijn wijsgerigheid bijna op, voor zijn doen, onbescheiden wijze tentoon heeft kunnen spreiden. Want ook dat mag gezegd worden, Bart had veel talenten, meer dan we wisten.

Wat ben ik blij dat we Bart carte blanche hebben gegeven toen hij voorstelde een nummer te maken over dieren in beeld: Kijken naar natuur. Daarmee realiseerde hij ook een wens die ik zelf koesterde. Het werd geen tijdschrift, maar een boek; welhaast een kroonnummer, en zeker een van de kronen op zijn werk.

Het eindredacteurschap van Bart was niet het eerste dat bij mij opkwam toen ik dacht over wat ik zou zeggen op zijn afscheid, maar iets anders wat ik met hem deelde: liefde voor de natuur, de dieren, de vogels en vooral de uilen. Het contact dat Bart en ik hierover hadden, raakt mij nog het meest. Toen Klazien en ik een paar jaar geleden in Bergen waren, nodigde Bart ons uit in zijn flat annex bibliotheek. Waren we dáár al van onder de indruk, ronduit ontroerd waren we toen hij ons meenam naar de vogelopvang. Prachtig om te zien hoe liefdevol hij met die arme beestjes omging: de uiltjes, de eenden, de zeevogels en af en toe zelfs een hertje, als vreemde eend in de bijt. Dit soort herinneringen aan Bart zal ik blijven koesteren. 
4 Tijdschrift voor Mediageschiedenis - I8 [I] 20I5

Ik ben dan ook heel blij hem ook privé te hebben gekend. Ook al zagen we elkaar weinig, het was heerlijk om met hem over de natuur te praten. Dat gesprek was wat mij betreft nog lang niet ten einde. En over einde gesproken: niemand beëindigde zijn e-mails altijd zo origineel als Bart. Behalve met zijn 'grootgroet' hield hij me ook wel op de hoogte van het dierenwelzijn. Op 2 september 2010 schreef hij:

“nb: intussen steenuiltje met gebroken en gekneusde poot opgelapt;

kan over een week of zo weg; mooi hè? nóg mooier dan tmg. “

En zo is het ...

Bernadette Kester 